\title{
ASSESSMENT OF MAIZE AND SOYBEAN PRICING
}

\author{
Muhammad Firdaus*), Fuza ${ }^{*}$, Hastuti**), and Dea Amanda**) \\ *) Department of Economics, Faculty of Economics and Management, IPB University \\ Jl. Kamper Wing 4 Level 5 Kampus IPB, Dramaga16680 Bogor, Indonesia \\ ${ }^{* *}$ Department of Resource and Environmental Economics, Faculty of Economics and Management, IPB University \\ Jl. Kamper Wing 4 Level 5 Kampus IPB, Dramaga16680 Bogor, Indonesia
}

\begin{abstract}
Prices of maize and soybean fluctuated significantly at both producer and consumer levels in Indonesia. This study aims to analyze the pricing of maize and soybean at the consumer level by employing the vector error correction model and to analyze the market behavior in determining consumer prices by using the game theory. The results show that maize prices at the consumer level are positively influenced by producer price, wholesale price, as well as gasoline price shocks and are also negatively affected by supply shocks. Soybean prices at the consumer level are negatively influenced by producer price shocks and are positively affected by wholesale price shocks. Shocks in terms of supply result in the fluctuating prices received by the consumers. It is due to the dominant pricing strategy, which is through collusion performed by the maize and soybean retailers. Some market efficiencies are encouraged to reach more stabilized prices.
\end{abstract}

Keywords: game theory, maize, soybean, market efficiency

Abstrak: Harga jagung dan kedelai berfluktuasi secara signifikan baik di tingkat produsen maupun konsumen di Indonesia. Penelitian ini bertujuan untuk menganalisis penetapan harga jagung dan kedelai di tingkat konsumen dengan menggunakan model koreksi kesalahan vektor dan menganalisis perilaku pasar dalam menentukan harga konsumen dengan menggunakan teori permainan. Hasil penelitian menunjukkan bahwa harga jagung di tingkat konsumen dipengaruhi secara positif oleh harga produsen, harga grosir, serta guncangan harga bensin dan juga dipengaruhi secara negatif oleh guncangan penawaran. Harga kedelai di tingkat konsumen dipengaruhi secara negatif oleh guncangan harga produsen dan dipengaruhi secara positif oleh guncangan harga grosir. Guncangan dalam hal penawaran mengakibatkan fluktuasi harga yang diterima konsumen. Hal ini disebabkan strategi penetapan harga yang dominan melalui kolusi yang dilakukan pengecer jagung dan kedelai. Beberapa efisiensi pasar didorong untuk mencapai harga yang lebih stabil.

Kata kunci: teori permainan, jagung, kedelai, efisiensi pasar

\footnotetext{
${ }^{1}$ Corresponding author:

Email: mfirdaus@ipb.ac.id
} 


\section{INTRODUCTION}

Based on some legal documents from the Government of Indonesia, both maize and soybean are categorized as strategic commodities as they are used as main materials for protein sources. The government targets national economic independence through food sovereignty efforts. Various strategies have been carried out by the government as an effort to increase food production. These efforts have not been able to achieve optimal results; therefore, the demand for food cannot be met by domestic food production.

As a strategic national commodity, the availability of maize must be maintained. This indicates the need for various efforts to control the stability of maize production annually. The availability of maize in Indonesia derives from the maize production outside of Java that has been experiencing a production growth of 7.54 percent per year over the last five years (the period of 2012 to 2016). The production growth is influenced by the growth of harvested areas outside of Java by 4.19 percent per year (Ministry of Agriculture [MoA], 2016).

In terms of consumption, maize is a good food alternative to rice. The pattern of maize consumption until 2015 was a fluctuating trend. The national maize consumption at the household level has increased by 457.24 thousand tons, with an increase of 23.58 percent from 2015. This increase is attributable to an increase in the consumption of fresh maize with husk as a substitution of staple food and an increase in the use of dried shelled maize for household consumption (MoA, 2016).

Soybean is themain source of protein, especially for the poor people in Indonesia. Soybean consumption is enjoyed in the form of processed tempe and tofu as the main side dishes. The data from the MoA (2016) shows that the average demand of soybean per year is 2.2 million tons. The need is met through imports of 68 percent due to insufficient production. Indonesia has become a tempe producer in the world with an average tempe consumption per person per year of $6.99 \mathrm{~kg}$ and that of tofu of $7.51 \mathrm{~kg}$. In addition, Indonesia is also the largest soybean market in Asia.
Soybean production that cannot meet the consumer demand is caused by the decrease of soybean harvested areas in Indonesia. In 2016, the national soybean harvested areas declined by 4.02 percent to 589.42 thousand hectares from 614.10 thousand hectares in 2015. Soybean production in 2016 decreased to 887.54 thousand tons due to the decreased production in Java at 12.55 percent and outside of Java at 0.10 percent (MoA, 2016).

Maize and soybean productions from farmers are distributed to all consumers in Indonesia through the marketing of maize and soybean, one of which through the traditional markets. The distribution of maize and soybean until the consumers receive them goes through a marketing chain that can affect prices at the producer as well as consumer levels.

Figure 1 shows the comparison between the world and domestic prices of maize and soybean throughout 2010-2018 (Center for Statistical Agency, 2019). The below line is the world price, which indicates the higher competitiveness of maize and also soybean compared to domestic production. In this study, some analysis based on the econometric model and game theory are conducted to formulate some recommendations to obtain more efficient pricing of maize and soybean. This will compensate for the lower competitiveness of both commodities.

Several studies have been conducted to analyze the movement of food prices in Indonesia, such as Kariyasa and Sinaga (2004); Gunawan and Firdaus (2012); Ramadhani, and Sumanjaya (2014). The methods used by authors might be improved. The more updated data are available. In this paper, after the econometric analysis is conducted, the game theory is applied to investigate the pricing behavior. Game theory is carried out to improve the quality of the econometric analysis. This tool might be used in many research fields. In Indonesia, the use of game theory is agriculture research is still limited. Some authors from other developing countries have applied this tool in agricultural economic studies related to optimization problems. Ozkan and Akcaoz (2002), also Podimata and Yannopoulos (2015) studied profit maximization in crop management such as maize, wheat, etc. They and this study started with an idea established by Roe (1996). 

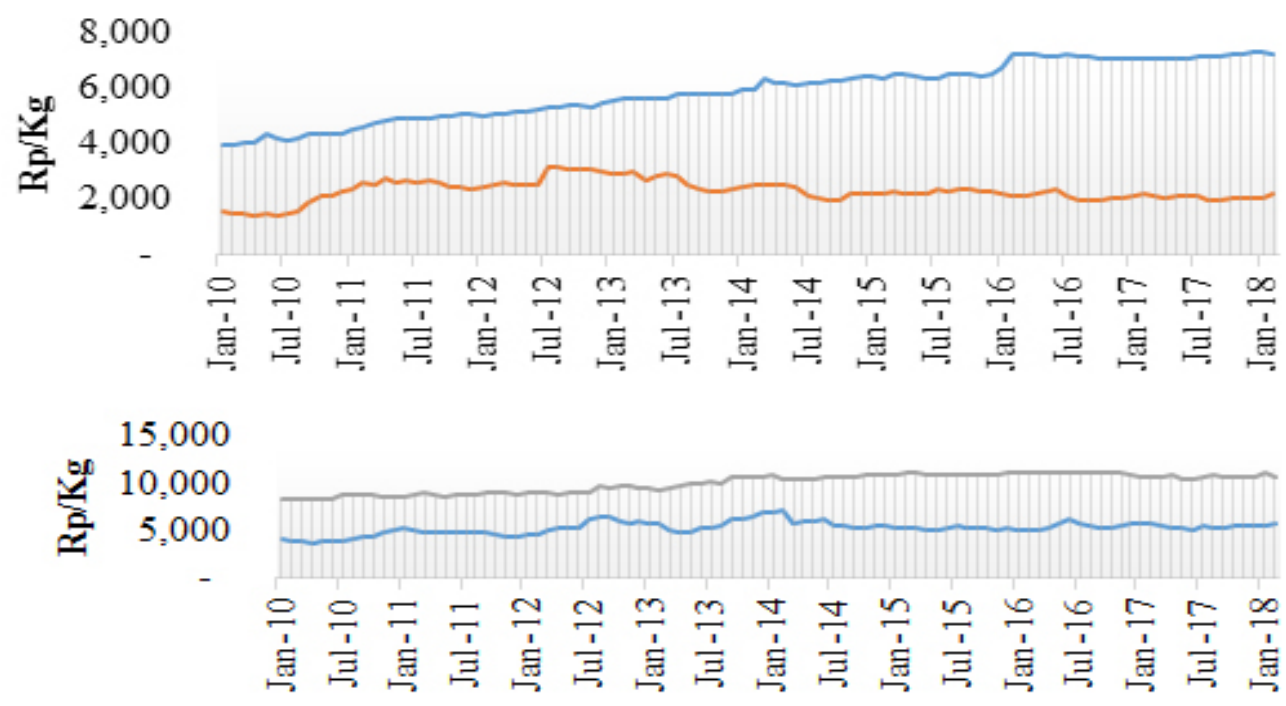

Figure 1. Comparison between World and Domestic Prices

The objectives of this study are to analyze the price movement of maize and soybean at the market by employing the Vector Error Correction Model and investigating market behavior of those commodities in determining consumer prices by using the game theory. The scope of this study is limited on analysis of consumer prices on two commodities of maize and soybean, and the investigation was conducted only in the wholesale market in East Jakarta, as the largest central market of food crops in Indonesia. Such movement is hypothesized related to the long supply chain from farmers to market. Some determinants are expected to influence the price level. Traders are expected to play an important role in price formation. This means the supply of maize and soybean is important in determining market price, but traders' behavior affect pricing phenomena in both commodities.

\section{METHODS}

The data used were primary and secondary data (Table 1). The primary data are analyzed to investigate market behavior in pricing were obtained from the results of interviewing in the form of questionnaires. Some respondents were selected purposively. They are maize and soybean wholesalers and retailers in the traditional markets in East Jakarta. Five retailers and five suppliers in Jakarta were interviewed. They were selected purposively as game theory; there is no inference procedure. The secondary data used to analyze the pricing of maize and soybean were the monthly data of the period of 2011-2015. The secondary data originated from Statistics Indonesia (BPS), the Food Outlook of the Ministry of Agriculture, the Agency for Cooperatives and Micro, Small and Medium Enterprises, and Trade Agency of DKI Jakarta. The software used in the research was Microsoft Excel 2007 to classify the data and then the data were processed using the program and E-views 8.

\section{Vector Error Correction Model (VECM) Method}

In this paper, the movement of maize and soybean prices is hypothesized determined by the market. The analysis conducted for the first objective of the study on the pricing of maize and soybean used the Vector Error Correction Model (VECM) analysis. VECM is a model of econometric analysis that can be used to find the solution to the time series variable problem that is not stationary and spurious regression in econometric analysis (Enders, 2012; Firdaus (2014)). In general, the model specification of VECM is as follows:

$$
\Delta \mathrm{y}_{\mathrm{t}}=\mu_{\mathrm{x}}+\mu_{1} \mathrm{x}_{\mathrm{t}}+\Pi_{\mathrm{x}} \mathrm{y}_{\mathrm{t}-1}+\sum_{i=1}^{k-1} \Gamma_{x i} \Delta y_{t-1}+\varepsilon_{t}
$$

Where: $\Delta y_{\mathrm{t}}$ (vector containing analyzed variables in the study); $\mu_{0 \mathrm{x}}$ (intercept vector); $\mu 1 \mathrm{x}$ (regression coefficient vector); $\Pi_{x}\left(\alpha \times \beta^{\prime}\right.$ where $\beta^{\prime}$ contains longterm cointegration equation); $y_{t-1}$ (in-level variable); $\Gamma_{x i}$ (regression coefficient matrix); k-1 (VECM order of VAR); $\varepsilon_{t}$ (error term) 
Table 1. Data types and sources

\begin{tabular}{lcc}
\hline Data Used & Unit & Source \\
\hline Maize Retail Prices & IDR & BPS and MoA \\
Soybean Retail Prices & IDR & BPS and MoA \\
Maize Producer Prices & IDR & BPS \\
Soybean Producer Prices & IDR & BPS \\
Maize Wholesale Prices & IDR & Diskumdag \\
Soybean Wholesale Prices & IDR & Diskumdag \\
Maize Supply & Ton & BPS \\
Soybean Supply & Ton & BPS \\
Gasoline Prices & IDR & BPS \\
\hline
\end{tabular}

Variables used to analyze the pricing were consumer prices (HK), producer prices (HP), wholesale prices (HG), supply (P), and gasoline prices (T). Thus, the model used in this study was:

$$
\begin{aligned}
\Delta \ln H K_{t}= & \alpha_{0}+\sum_{i=1}^{1} \alpha_{1} \ln H P_{t-1}+\sum_{i=1}^{1} \alpha_{2} \ln H G_{t-1}+ \\
& \sum_{i=1}^{1} \alpha_{3} \ln P_{t-1}+\sum_{i=1}^{1} \alpha_{4} \ln T_{t-1}+\gamma E C T_{t-1}+\varepsilon_{t}
\end{aligned}
$$

Where: $\mathrm{HK}_{\mathrm{t}}$ (commodity retail price of the $\mathrm{t}^{\text {th }}$ period $(\mathrm{IDR} / \mathrm{kg})$ ); $\mathrm{HP}_{\mathrm{t}}$ (commodity producer price of the $\mathrm{t}^{\text {th }}$ period (IDR $/ \mathrm{kg}$ )); $\mathrm{HG}_{\mathrm{t}}$ (commodity wholesale price of the $\mathrm{t}^{\text {th }}$ period (IDR $/ \mathrm{kg}$ )); $\mathrm{P}_{\mathrm{t}}$ (commodity supply at the production central at the $\mathrm{t}^{\text {th }}$ period (Ton)); $\mathrm{T}_{\mathrm{t}}$ (gasoline price of the $\mathrm{t}^{\text {th }}$ period (IDR/liter)); $\alpha_{\mathrm{ij}}$ (regression coefficient of VECM); $\varepsilon_{t}$ (error term (residual) at the $\mathrm{t}^{\text {th }}$ period); $\mathrm{t}$ (monthly period from January 2011 to December 2015).

The steps applied in analyzing the data began with a preestimation test. There are consisting of stationarity test, optimal lag test, VAR stability test, and cointegration test. If the data had been proven to be stationary at the first difference and had a cointegration equation, then the next step would be to conduct VECM estimation to determine the effects of research variables on consumer prices. To find out the consumer price responses to shocks occurring on the observed research variables, the Impulse Response Function (IRF) analysis was made. The final step was the Forecast Error Variance Decomposition (FEVD) analysis that was used to determine the shock contribution of the observed research variables in influencing consumer prices.

\section{Data Stationarity Test}

The first step in VECM testing is the stationarity test (unit root test) of all variables. The stationarity test can be performed using Augmented Dickey-Fuller (ADF) at the same degree (level or different) to obtain stationary data (Enders, 1995). All variables are stationary (does not contain a unit root) if the statistic ADF value is smaller than the Mackinnon critical value (Gujarati, 2013).

\section{Optimal Lag Test}

This testing is important in the VAR model to determine the optimum lag number in the model. Optimum lag determination can be done by looking at the asterisk sign information on Akaike Information Criterion (AIC), Schwarz Criterion (SC), and Hannan-Quinn Criterion (HQ).

\section{VAR Stability Test}

VAR stability test is done to look at the roots of the polynomial function. If the absolute value of all the roots of the polynomial function $<1$, then the VAR model is considered stable; therefore the Impulse Response Function (IRF) and Forecast Error Variance Decomposition (FEVD) generated are deemed valid (Firdaus, 2014).

\section{Cointegration Test}

The cointegration test used the Johannsen cointegration test in the study. This testing was conducted to see the cointegration between non-stationary variables. Cointegration can be interpreted as a long-term equilibrium relationship between variables. The equation is cointegrated if the value of trace statistic $>$ critical value.

Impulse Response Function (IRF)

Impulse Response Function (IRF) can see the dynamic behavior of VECM through the response of each endogenous variable to that variable' shock as well as to other endogenous variables. In addition, IRF also functions to see how long the effect of a variable' shock on other variables lasts or returns to the equilibrium point. The IRF analysis in this study was conducted to see the consumer price responses to the shocks on research variables. The time period used to project IRF was 60 periods ahead. 
Forecast Error Variance Decomposition (FEVD)

The FEVD method serves to see the movement proportion of the influence of a variable' shock on other variables in the current and future periods (Ajija et al. 2011). Firdaus (2011) has stated that the FEVD method can serve to determine the factors that affect the fluctuations of particular variables. In this study, FEVD would discuss the contribution of the shocks on research variables in explaining consumer prices. The time period used in projecting this FEVD was 60 periods ahead.

\section{Game Theory Analysis}

Game theory is aimed to determine the optimal strategy selection in a competitive situation. Each theory model includes players, strategies, and payoff. Players are decision-makers. Strategies are potential choices that can be made by the players. The payoff is the reward or consequence of a combination of strategies by two players. The payoff matrix refers to all of the results of the strategies of the players (Tadelis, 2013).

Players in this game were retailers. The payoff expected by retailers was the increased revenue through a change in pricing strategy in the market. Retailers set a selling price at a high price and a low price. The completion of this game was done through an assessment of the payoff that provided the highest utility. The payoff was determined from retailers' decision in determining the strategy.

The analysis conducted used the sequential bargaining game. Sequential bargaining game was done under the condition of complete and perfect condition, meaning that each player knew the function of reward (payoff) and the history of the strategies implemented by each player. The procedure in this game was that one of the players performed a strategy first (move first), and the other player responded to that action.

\section{RESULTS}

Impulse Response Function (IRF) was used to observe the movement and response between the variables in the current period and to forecast variables' conditions in case of shocks. In this study, IRF analysis was used to observe the responses given by consumer prices to the shocks on research variables 60 periods ahead. The significant variables affecting maize consumer prices are producer prices, wholesale prices, supply, and gasoline prices, whereas the variables affecting soybean consumer prices are producer prices and wholesale prices.

Figure 2 shows that the maize producer price shock of one standard deviation in the first month has not been responded by consumer prices. The increase in producer prices by one standard deviation in the second month is positively responded by consumer prices with an increase of 0.007 percent and continues to decline until the sixth month. In the seventh month, consumer prices respond positively to producer price shocks of 0.003 percent and reach a stable condition in the thirteenth month. This is supported by the study of Gilbert and Morgan (2010) that has concluded that food prices affect the consumer prices determined by retailers.

The first month of maize wholesale price shock has had no response from consumer prices (Figure 3). In the second month, an increase of one standard deviation of wholesale prices is positively responded by consumer prices with an increase of 0.002 percent and continues to decline. In the thirteenth month, wholesale price shocks begin to reach equilibrium in the long run, where consumer prices respond to wholesale price shocks of 0.001 percent.

Arby and Ghauri (2016) has proved that food prices at the wholesale level affect the prices at the consumer level. Changes in consumer prices can be attributed to seasonal demand changes in the short term and seasonal supply changes in the long term. For agriculture commodities, there is a lag between market price information and response in production. This seasonal supply changes directly affect the wholesale prices that are ultimately transmitted to consumer prices.

Consumer prices have not responded to maize supply shock in the first month (Figure 4). In the second month, the increase of one standard deviation of maize supply in East Java is responded negatively by consumer prices at 0.001 percent. In the fourth month, supply shock begins to receive a positive response from consumer prices with an increase of 0.0005 percent. Consumer price responses to supply shocks begin to reach equilibrium in the fourteenth month with an increase in consumer prices by 0.001 percent. This is in line with the study of Serra and Gill (2012) that has concluded that stock procurement can significantly reduce maize price fluctuations and stabilize commodity price levels in the market. 
Response of LNHK to Cholesky

One S.D. LNHP Innovation

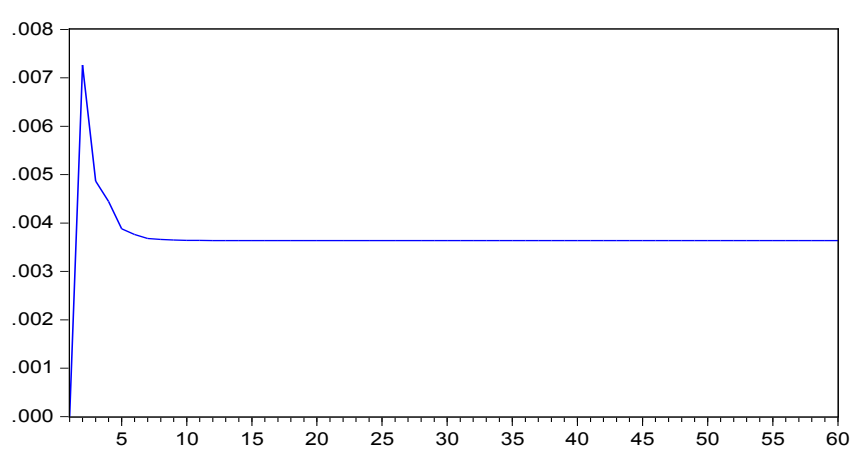

Figure 2. Consumer price responses of maize commodity to producer prices

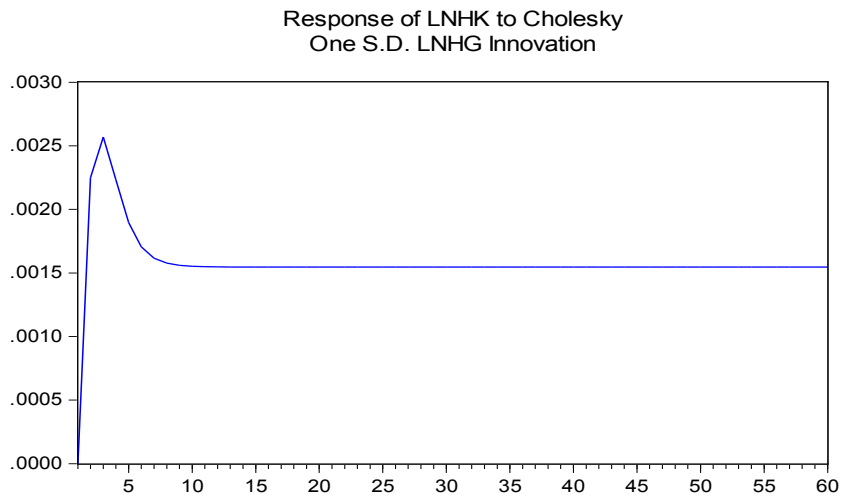

Figure 3. Consumer price responses of maize commodity to wholesale prices

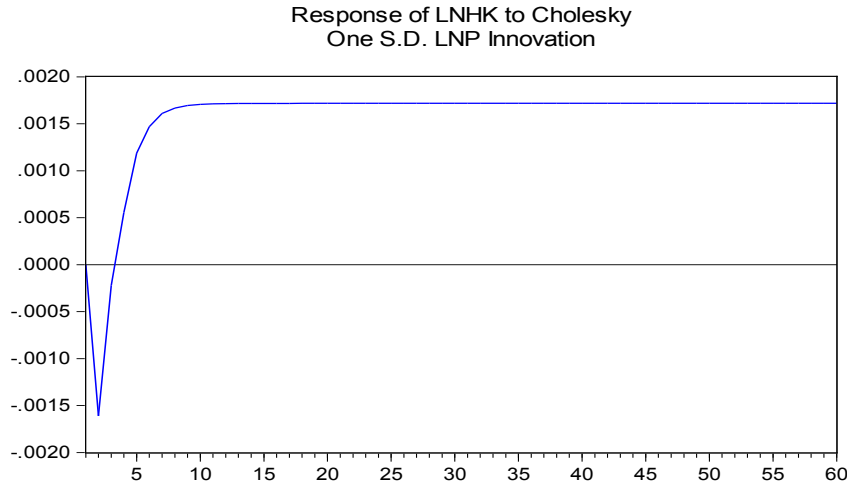

Figure 4. Consumer price responses of maize commodity to supply

An increase of one standard deviation of gasoline prices has not been responded by consumer prices in the first month (Figure 5). In the second month, gasoline price shock is responded positively by consumer prices at 0.001 percent. The response is getting smaller and smaller. In the fourteenth month, consumer prices begin to reach equilibrium in response to gasoline price shocks with an increase of 0.0007 percent. The results of this study is supported by the study of Urbanchuk
(2007) that has proved that the increase in gasoline prices affect the prices of food at the consumer level. The increase in gasoline price will rise transportation costs and input prices such as fertilizers, etc.

Soybean producer price shock of one standard deviation in the first month has not been responded by consumer prices (Figure 6). The increase in producer prices by one standard deviation in the second month is responded negatively by consumer prices with a decrease of 0.008 percent and continues to decline. In the fourth month, consumer prices respond to producer price shock with a decrease of 0.011 percent. The stable condition begins starting from the twelfth month. This is supported by the study of Ulke and Ergun (2013) that has proved that there has been a one-way relationship between producer prices and consumer prices in the economic analysis of Turkey from 2003 to 2013.

In the first month, the soybean wholesale price shock has not been responded by consumer prices (Figure 7). This is due to the length of the production of soybean. In the second month, an increase of one standard deviation of wholesale prices is positively responded by consumer prices with an increase of 0.010 percent and continues to increase. In the sixth month, consumer prices respond to wholesale price shock of 0.011 percent. The equilibrium, in the long run, is reached starting from the fourteenth month.

\section{Contribution of Research Variables in Affecting Consumer Prices}

Forecast Error Variance Decomposition (FEVD) aims to explain the contribution of each variable to the shock that it causes to the main variables observed. This study aimed to describe the magnitude of the percentage contribution of the shock on each research variable so that the strengths and weaknesses of each variable in influencing consumer prices could be seen. The time period used in explaining this FEVD is 60 periods.

In the first year, the role of maize consumer prices in explaining the fluctuation in consumer prices was still dominant, amounting to 98.90 percent, as seen in Figure 8. Other variables did not really affect the fluctuation of consumer prices. Producer prices influenced at 0.81 percent, wholesale prices influenced at 0.15 percent, supply influenced at 0.09 percent, and gasoline prices influenced at 0.04 percent. 


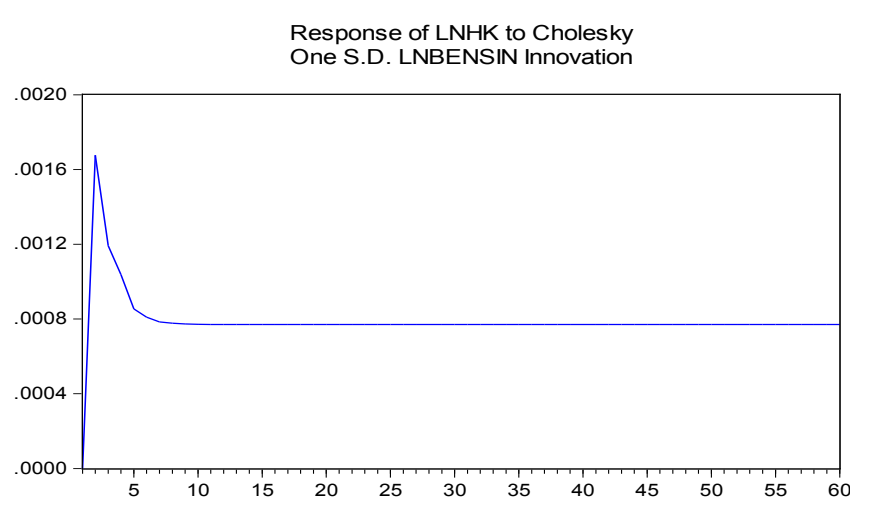

Figure 5. Consumer price responses of maize commodity to gasoline prices

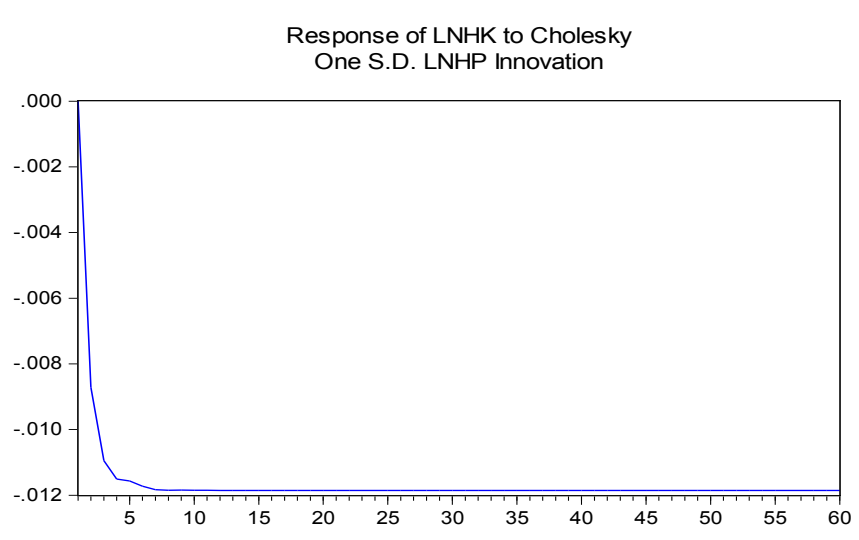

Figure 6. Consumer price responses of soybean commodity to producer prices

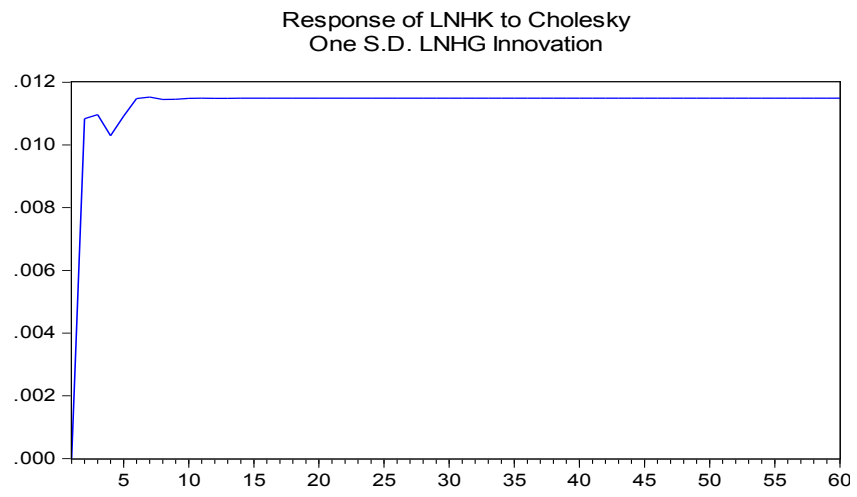

Figure 7. Consumer price responses of soybean commodity to wholesale prices

In the second year to the fifth year, the magnitude of the influence of consumer prices on the fluctuations of consumer prices has had an increase in contribution and has still been dominating at 99.02 percent. The variables of producer prices, wholesale prices, and gasoline prices have had an increase in contribution but have not significantly influenced consumer price fluctuations. The contributions of each variable are, respectively,
0.68 percent, 0.12 percent, and 0.03 percent. The supply variable has experienced an increase in contribution to consumer price fluctuations. In the fifth tear, the supply contribution to maize consumer price fluctuations is only 0.13 percent.

In the first year, the role of soybean consumer prices in explaining consumer price fluctuations was still dominant, amounting to 92.30 percent (Figure 9). Other variables did not significantly affect consumer price fluctuations. Producer prices influenced at 3.71 percent, wholesale prices influenced at 3.57 percent, supply influenced at 0.38 percent, and gasoline prices influenced at 0.01 percent.

In the second year to the fifth year, the magnitude of the influence of consumer prices on consumer price fluctuations has experienced a decrease in contribution and has still been dominating at 91.67 percent. The variables of producer prices, wholesale prices, and gasoline prices have experienced an increase in contribution but have not significantly affected consumer price fluctuation. The contributions of each variable are, respectively, 4.09 percent, 3.86 percent, and 0.01 percent. Supply variable has experienced a decrease in contribution to consumer price fluctuations. In the fifth year, the supply contribution to soybean consumer price fluctuations is only 0.35 percent.

\section{Pricing Behavior}

In real conditions in the field, maize retailers in the traditional markets of East Jakarta predominantly decided to set the selling prices through collusion. The selling prices determined by retailers will depend on the prevailing selling prices in the market set by other retailers. This is done in order to gain a huge profit. The determination of selling prices through collusion is also based on trust among fellow retailers, so retailers will not change their selling prices to be more competitive through lower prices.

Table 2 shows when one retailer has decided to set a price by collusion, the maize price set by retailers is then IDR20,000 per kilogram. When retailers use a competitive pricing strategy, then the maize price set by retailers is IDR18,000 per kilogram. If one of the retailers uses their dominant strategy, which is collusion pricing, while another retailer uses competitive pricing through lower prices, then the profit obtained by the 
retailer with competitive pricing will be higher. This is because the market share owned by the retailer with a competitive price will be bigger than the retailer with collusion selling price.

Over time, retailers with collusion pricing will determine the selling prices by way of competition; hence the prevailing selling prices in the market become similar and the profit of each retailer becomes lower with a balanced market share. This suggests that bigger profit will be obtained by retailers if they set prices by collusion.

Table 3 shows that the prevailing soybean price in the market when retailers decide to collude is IDR12,000 per kilogram. When retailers use a competitive pricing strategy, the soybean price set by retailers is IDR10,000 per kilogram. If one of the retailers uses collusion pricing strategy while another retailer uses competitive pricing strategy, then the profit of the retailer who uses competitive pricing strategy will be higher. This is the effect of the large market share held by the retailer who uses competitive pricing strategy.

This condition will not last long. In the end, the soybean price in the market will reach equilibrium at a price of IDR10,000 per kilogram. This is because of a change in pricing strategy by retailers from collusion to competition. Thus, the profit received will be balanced in accordance with the prevailing market share. This phenomenon indicates the need for cooperation among retailers in determining the selling prices of soybean in the market to gain greater profit.

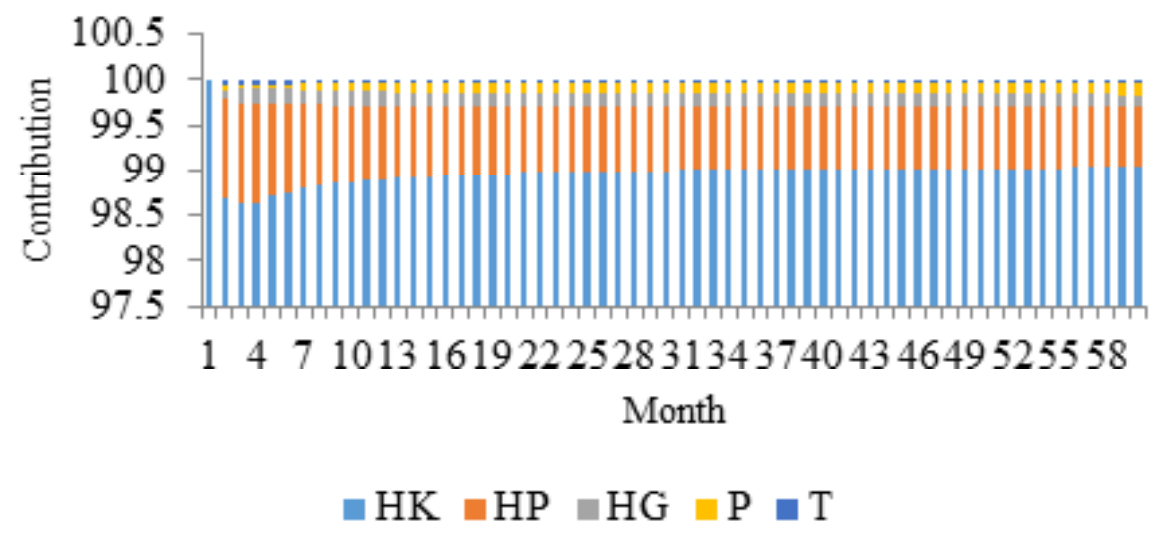

Figure 8. The contributions of producer prices, wholesale prices, supply, and gasoline prices in affecting the consumer prices of maize commodity

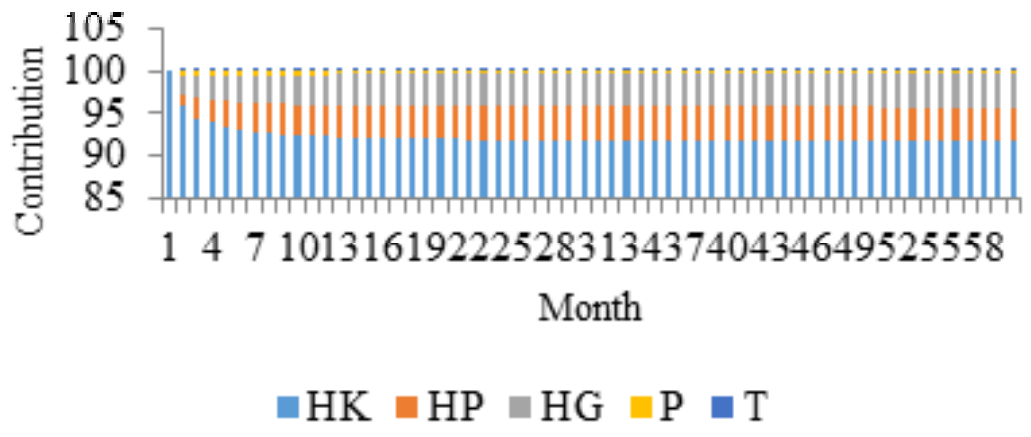

Figure 9. The contributions of producer prices, wholesale prices, supply, and gasoline prices in affecting the consumer prices of soybean commodity

Table 2. The matrix of maize pricing strategies by the retailers in the traditional markets of East Jakarta

\begin{tabular}{ccc}
\hline \multirow{2}{*}{ Retailer 1 } & \multicolumn{2}{c}{ Retailer 2 } \\
\cline { 2 - 3 } & Competition & Collusion \\
\hline Competition & 18000,18000 & 18000,20000 \\
Collusion & 20000,18000 & $20000,20000^{*}$ \\
\hline
\end{tabular}

Description: *Nash equilibrium 
Table 3. The matrix of soybean pricing strategies by the retailers in the traditional markets of East Jakarta

\begin{tabular}{ccc}
\hline \multirow{2}{*}{ Retailer 1 } & \multicolumn{3}{c}{ Retailer 2 } \\
\cline { 2 - 3 } & Competition & Collusion \\
\hline Competition & 10000,10000 & 12000,10000 \\
Collusion & 10000,12000 & $12000,12000^{*}$ \\
\hline
\end{tabular}

Description: *Nash equilibrium

The real condition of soybean pricing by retailers in the traditional markets in East Jakarta is done through collusion. Selling price determination by retailers will depend on the market prices set by other retailers. The determination of soybean selling prices in the market also occurs due to the trust between fellow retailers. This is what causes retailers not to change their selling price strategy to obtain huge profit.

According to Gibbons (1992), the optimum strategy is a strategy that provides the biggest payoff, so there is no incentive for the players to change the strategy they use in the game. The results showed that the determination of the selling prices of maize and soybean in collusion is the optimum strategy because it has generated a greater payoff. This condition will not provide an incentive for the players to change their strategy. The condition in competitive pricing is a balanced strategy, but it is not the optimum strategy (inefficient) because it still provides an incentive to change the strategy to achieve a bigger payoff.

The structure of agricultural commodity markets is generally imperfect competition. This condition can cause asymmetric price transmission (Miller, 2001; Mayer, 2004). The structure of the maize market at the farmer level tends towards an oligopoly market because the ratio of maize buyers to farmers is very limited. This causes the bargaining position of maize prices at the farmer level to be very weak. On the other hand, the dry shelled maize prices at the producer level in the Province of Gorontalo increases. This is due to strong demand in national and export markets, especially to meet the needs of animal feed.

The pricing system is generally done by higher marketing institutions because they know the development of soybean prices better. The soybean pricings of mature pods and young pods do not differ even though some marketing institutions set the price of soybean with a bargaining system.
The market structure of maize and soybean commodities at the retail level is imperfect competition. This causes the fluctuation of prices at the consumer level due to the bargaining power of retailers. In this case, retailers act as the price maker who has the opportunity in pricing. The government has intervened in controlling prices of maize and soybean at the consumer level through Law No. 7 of 2014 on Trade. The policy has not been fully realized as there are influencing factors such as market concentration that influence market behavior in pricing. This is a major issue in agricultural marketing programs (USDA, 2016). Some previous studies also address the role of government intervention regarding food system. Rocha (2009) explained the function of such policy to improve food security, whereas, in Indonesia, maize and soybean have very significant role.

\section{Managerial Implications}

Some findings from this study support the need for better marketing actions for both maize and soybean. In order to improve pricing efficiency for the cases of maize and soybean in Indonesia, some efforts are needed, such as reducing the disparity between farm gate and retail prices. This will increase farmers' share, which still ranges from 5 to 20 percent on average. The higher share will bring more welfare to the farmers. This must be completed by lowering food losses along the chain. In Indonesia, the rate of losses from the transporting of products may reach 20 to 30 percent of volume.

Such interventions may be implemented through some efforts. Based on the results of the analysis, the significant factors are related to supply and role of traders. Thus, some efficiencies are needed along the chain. Some following actions might be carried out from the farm to the retail market, in order to create more transparent and fair pricing: 1) establishing marketing institution at farmer level or wet market level, such as auction market. It will improve price establishment by considering participation from all stakeholders. This 
will reduce the strength of players who make collusion; 2) empowering information and communication technology, which help faster transmission process from market to producers or vice versa. Market places are currently substantially developed in Indonesia. The information may be delivered to farmers and traders by using application in smartphone.

\section{CONCLUSIONS AND RECOMMENDATIONS}

\section{Conclusions}

This study finds that the maize price at the consumer level is positively and significantly affected by producer price, wholesale price, and gasoline price shocks and are also negatively and significantly affected by supply shocks. The soybean prices are negatively and significantly affected by producer price shocks and are also positively and significantly affected by wholesale price shocks. Retailers' behavior in the pricing of both maize and soybean commodities is done in collusion. Pricing is established to attain a big profit. Collusion pricing has resulted in consumers having no choice of traders in buying maize and soybean commodities because the prevailing market prices are similar.

\section{Recommendations}

The consumer prices of maize and soybean tend to fluctuate due to supply shocks and long marketing chain. Therefore, the realization of good government intervention in maize and soybean pricing is needed. Government policy necessary to ensure price stability can be implemented through direct pricing as well as through the control of maize and soybean supply. Some current technology, such as internet of things (IoT), may be used to support access of producers and traders on market price information.

Some further studies might be carried out to improve the quality of the study. Game theory analysis can be expanded into other commodities and locations in Indonesia. This instrument is effective to reach some policies regarding marketing efficiency in agriculture.

\section{REFERENCES}

Arby MF, Ghauri SP. 2016. The relationship between wholesale price index and consumer price index.
SBP Sfaffnotes 3: 1-8.

Enders W. 1995. Applied Economic Time Series. Iowa University. New York: J Wiley.

Firdaus M. 2014. Application of Time-Series and Data Panel Model. Bogor: IPB Pr.

Gibbons R. 1992. Game Theory for Applied Economist. New Jersey: Princeton University Pr.

Gilbert C, Morgan W. 2010. Food price volatility. Philosophical Transactions of the Royal Society 365: 3023-3034.

Gunawan I, Firdaus M. 2012. Integration among Regional Vegetable markets in Indonesia. Journal ISSAAS 18: 96-106.

Karisayasa K, Sinaga BM. Determinants of Maize Price Behavior in Indonesia. Jurnal Agro Ekonomi 22: 167-194.

Meyer J, Taubadel CS. 2004. Asymmetric Price Transmission: a Survey. Journal of Agricultural Economics 55: 581-611.

Miller DJ, Hayenga ML. 2001. Price cycles and asymmetric price transmission in the US Pork Market. American Journal of Agricultural Economics 83: 551-562.

[MoA) Ministry of Agriculture. 2016. Annual Report. Jakarta: Ministry of Agriculture.

Podimata MV, Yannopoulos PC. 2015. Evolution of Game Theory Application in Irrigation Systems. Agriculture and Agricultural Science Procedia 4: $271-281$

Ramadhani DA, Sumanjaya R. 2014. Determinants of Soybean Availability in IDnonesia. Jurnal Ekonomi dan Keuangan 2: 131-145.

Rocha C. 2009. Food Insecurity as Market Failure: A Contribution from Economics. Journal of Hunger and Environment Nutrition 1:5-22.

Roe TL. 1996. Application of Game Theory in Agricultural Economics: Discussion. American Journal of Agricultural Economics 78: 761-763.

Serra T, Gill JM. 2012. Price Volatility in Food Markets: Can Stock Building Mitigate Price Fluctuations? Selected Paper prepared for presentation at The International Association of Agricultural Economist (IAAE) Triennial Conference, Foz do Iguacu, Brazil,.

Suryana A, Mardianto S, Ikhsan M. 2001. Rice Economics. Jakarta: LPEM-UI.

Tadelis S. 2013. Game Theory: An Introduction. New Jersey: Princeton University Press.

Ulke V, Ergun U. 2013. The Relationship Between Consumer Price and Producer Price Indices In Turkey. International Journal of Academic 
Research in Economics and Management Sciences 3: 205-222.

Urbanchuk J. 2007. The Relative Impact of Maize And Energy Prices In The Grocery Aisle. LECG
Director Notes.

USDA. 2016. Agricultural Marketing Service Achievement Report. UK: USDA. 